\title{
Trends and gaps of the scientific literature about the effects of fire on Brazilian Cerrado
}

\author{
Filipe Viegas de Arruda* (1D, Diego Guimarães de Sousa ${ }^{l, 2}$, Fabrício Barreto Teresa ${ }^{l}$, \\ Vitor Hugo Mendonça do Prado ${ }^{1}$, Hélida Ferreira da Cunha ${ }^{1}$ \& Thiago Junqueira Izzo \\ ${ }^{1}$ Universidade Estadual de Goiás, Programa de Pós-Graduação em Recursos Naturais do Cerrado, Anápolis, GO, Brasil \\ ${ }^{2}$ Instituto Brasileiro do Meio Ambiente e dos Recursos Naturais Renováveis, GO, Brasil \\ ${ }^{3}$ Universidade Federal de Mato Grosso, Departamento de Botânica e Ecologia, Cuiabá, MT, Brasil \\ *Corresponding author: Filipe Viegas de Arruda, e-mail: filipeeco@gmail.com
}

ARRUDA, F. V., SOUSA, D. G., TERESA, F. B., PRADO, V. H. M., CUNHA, H. F., IZZO, T. J. Trends and gaps of the scientific literature about the effects of fire on Brazilian Cerrado. Biota Neotropica. 18(1): e20170426. http://dx.doi.org/10.1590/1676-0611-BN-2017-0426

\begin{abstract}
Fire management is an important issue in the Brazilian Cerrado, since both anthropogenic high intensity fires and complete fire suppression can reduce the biodiversity in this biome. In this paper, we highlight the trends in scientific literature about fire effects in the Cerrado, aiming to detect possible gaps and to indicate directions of future scientific research. We searched for articles in the periodic database Web of Knowledge from 1991 to 2016, and observed an increase in the number of publications throughout the years. Most articles were associated with Brazilian institutions (58\%), followed by those with collaboration between Brazilian and international institutions (33\%), and those published by authors exclusively from international institutions (9\%). Most articles addressed the effects of fire on biodiversity (77\%), followed by articles about abiotic environment (19\%), and then biotic interactions or interactions between organisms and environment (4\%). The most studied taxonomic group was plants $(75 \%)$, followed by mammals $(8 \%)$ and insects $(6 \%)$, with the remaining taxa comprising about $11 \%$ of publications. The Federal District was the federative unit with the greatest number of studies (31\%). The majority of studies was conducted in areas with fewer fire events, whereas areas with major incidence of fires are poorly studied. Our data shows that studies on the effect of fires on the Brazilian Cerrado are geographically and taxonomically biased. This lack of knowledge limits the extrapolations about the effects of fire on this biome. Therefore, we emphasize the need for investment in research in areas with high fire frequency and also for an increase in knowledge about these effects on the biota, especially on the fauna. This action is fundamental to support the development of public policies for effective and directed fire management in the Cerrado.
\end{abstract}

Keywords: Burning, Scientometrics, Biodiversity Hotspots, Savanna, Perturbation.

\section{Tendências e lacunas na literatura científica sobre os efeitos do fogo no Cerrado Brasileiro}

Resumo: O manejo do fogo é uma questão importante no Cerrado brasileiro, pois tanto os incêndios antropogênicos de alta intensidade, quanto a sua supressão completa podem reduzir a biodiversidade neste bioma. Neste artigo, destacamos as tendências na literatura científica sobre os efeitos do fogo no Cerrado, com o objetivo de detectar possíveis lacunas e indicar direções de futuras pesquisas científicas. Buscamos artigos na base de periódicos Web of Knowledge no período de 1991 a 2016, e observamos um aumento no número de publicações ao longo dos anos. A maioria dos artigos foi associada a instituições brasileiras (58\%), seguidos por colaborações entre instituições brasileiras e internacionais (33\%) e publicações de autores exclusivamente de instituições internacionais (9\%). A maioria dos artigos abordou os efeitos do fogo na biodiversidade (77\%), seguido de artigos sobre o ambiente abiótico (19\%), e interações bióticas ou interações entre organismos e o ambiente (4\%). O grupo taxonômico mais estudado foi plantas (75\%), seguido de mamíferos $(8 \%)$ e insetos $(6 \%)$. Os táxons restantes incluem $11 \%$ das publicações. O Distrito Federal foi a unidade federativa com o maior número de estudos (31\%). A maioria dos estudos foi realizada em áreas com menos queimadas, enquanto as áreas com maior incidência de fogo são mal estudadas. Nossos dados mostram que os estudos sobre o efeito do fogo no Cerrado brasileiro são enviesados do ponto de vista geográfico e taxonômico. Esta falta de conhecimento limita as extrapolações sobre o efeito do fogo neste bioma. Portanto, enfatizamos a necessidade de investimentos para pesquisas em áreas com alta freqüência de queimadas e a necessidade em aumentar o conhecimento sobre estes efeitos na biota, especialmente na fauna. Esta ação é fundamental para apoiar o desenvolvimento de políticas públicas para uma gestão efetiva e direcionada do fogo no Cerrado.

Palavras-chave: Queimadas, Cienciometria, Hotspots de Biodiversidade, Savana, Perturbação. 


\section{Introduction}

The Brazilian Cerrado comprises an area of 2 million $\mathrm{km}^{2}$ and is home to a rich and diverse fauna and flora (Ribeiro \& Walter 2008). In this biome, there are more than 1,000 terrestrial vertebrates and 12,000 plant species (Myers et al. 2000, Mendonça et al. 2008), and about $80 \%$ of those plant species are endemic (Lenthall et al. 1999). Given its wide range, the Cerrado is constituted by different phytophysiognomies that vary from open areas to forest formations (Oliveira-Filho \& Ratter 2002, Lenthall et al. 1999). Therefore, we cannot assume that the Brazilian Cerrado is homogeneous since it hosts a large variation in soil structure, geomorphological formation, drain basins and associated vegetation (Silva et al. 2006, Furley 1999).

The Cerrado exhibits remarkable characteristics such as (i) poor, acidic soil with a high concentration of aluminum (Queiroz-Neto 1982, Reatto et al 1998), (ii) climatic seasonality with well-defined rainy and dry seasons, and (iii) resistance to fire (Coutinho 1990). In fact, fire has been considered the prevalent force driving the evolution of biota in this biome (Simon et al. 2009). Fire can influence community composition (Oliveras et al. 2012, Vieira \& Briani 2013, Silvério et al. 2015, Abreu et al. 2017), soil properties and regional climate (Bustamante et al. 2012, Wendling et al. 2014). In fact, fire can act as either a natural or an anthropic disturbance in the Cerrado. In non-protected areas, the frequency and intensity of fires has increased due to recent expansion of agriculture and livestock, with potential negative effects on the biota (Bowman et al. 2011). However, this issue is controversial since some studies have shown that fire frequency is reduced in protected areas of the Cerrado, with negative consequences for biodiversity (Moreira 2000, Roitman et al. 2008, Cardoso et al. 2009, Pinheiro \& Durigan 2009, Pinheiro et al. 2010). Thus, not only the increase but the changes in the frequency of fires are of great concern for the conservation of the Cerrado's biodiversity (Pivello 2011, Abreu et al. 2017).

Several studies have been conducted to understand the effects of fire on different environmental aspects of the Cerrado (e.g. Tubelis et al. 2009, Fagundes et al. 2015, Abreu et al. 2017). Indeed, the understanding of the effects of fire and also of fire suppression on biodiversity and ecosystem function is fundamental to a satisfactory establishment of public policies focusing on natural resource management (Durigan \& Rattter 2016). Nevertheless, due its wide range, the Cerrado is also a spatially heterogeneous biome (Silva \& Bates 2002). Considering that fire or fire suppression can have different effects in different regions, there should be studies conducted across a wide geographical range, and spatially replicated across the biome. The predominance of studies in the vicinity of traditional research centers (Nabout et al. 2015) or the non-equitable spatial distribution of infrastructure providing unequal access to many areas may generate a geographic asymmetry on the development of studies in the Cerrado. Also, the occurrence and frequency of wildfires are not spatially homogeneous (Pereira Júnior et al. 2014). Thus, the spatial variation in fire events may also benefit the development of studies, given the urgency in obtaining parameters for fire management in those environments.

In this study, we performed a scientometric evaluation of the studies related to fire in the Cerrado biome, seeking to understand the temporal and spatial trends in publications about this theme. Specifically, we (i) evaluated the temporal increment of the number of articles; (ii) highlighted the main taxonomic groups or themes addressed in the studies; (iii) determined the journals with the most publications about fire in the Cerrado; (iv) evaluated the possible biases in the location where studies were conducted and the fire frequency in the Cerrado; and (v) indicated directions for future studies.

\section{Material and Methods}

We used the Web of Science database (www.isiknowledge.com) to access articles about the influence of fire in the Cerrado biome. We considered publications from 1991 to 2016, since abstracts are only available in this database from 1991 to 2016, and this research is based on abstracts. The search was restricted to articles using the words ("fire*") AND (("savanna*") OR ("cerrado*")) AND ("Brazil*") in the topics.

For each article, we evaluated the title, keywords and abstract, to collect the following information: (1) publication year; (2) the institution, the nationality and state of the institution where the authors were associated at the time the manuscript was written; (3) taxonomic group (i.e. humans, mammals, amphibians, birds, reptiles, fishes, insects, non-insect invertebrates, microorganisms, plants and fungi); (4) journal in which it was published; and (5) geographic location(s) of the research.

To assess the temporal trend in the number of articles, we used Pearson correlation between the year of the publication and the number of articles published in that given year. The same test was performed separately for each taxonomic group to check the temporal trend in articles by taxonomic group. We also used Pearson correlation to test separately the relation of the number of authors and first authors by state with the frequency of fire occurrences in that given state. In this case, the states were considered as sample units since data on fire occurrence are easily available on the Instituto Nacional de Pesquisas Espaciais (INPE) website (https://queimadas.dgi. inpe.br/queimadas). The Federal District is not a formal state, but was considered a sample unit in the present study. These data refer to fire events from 1992 to 2015 . We then built maps with the number of fire events as well as with the number of published papers within this period for each state. One limitation of the INPE dataset is that it does not distinguish fire occurrences between natural vegetation and crops or pastures. We recognize this limitation but we acknowledge that fire events in crops and pastures pose a high risk for the natural vegetation of the Cerrado. Therefore, these limitations do not detract our inferences about the relation between fire frequency and number of studies in the states of this biome.

\section{Results}

We found 288 articles from 1991 to 2016 addressing fire in the Brazilian Cerrado. Among these articles, 166 (58\%) have authors associated only with a Brazilian institution. We counted a total of 96 articles with collaboration between Brazilian and international institutions (33\%) and a small part (26 articles, 9\%) published only by authors affiliated with international institutions.

We found an increasing temporal trend in the number of articles published over the years $(\mathrm{r}=0.86 ; \mathrm{p}<0.001)$ (Figure 1). Most articles ( 223 , totaling $77 \%$ ), addressed the effect of fire on biodiversity. Another $53(18 \%)$ focused on the association between fire and abiotic variables. Among the studies about abiotic factors, the highlighted factor

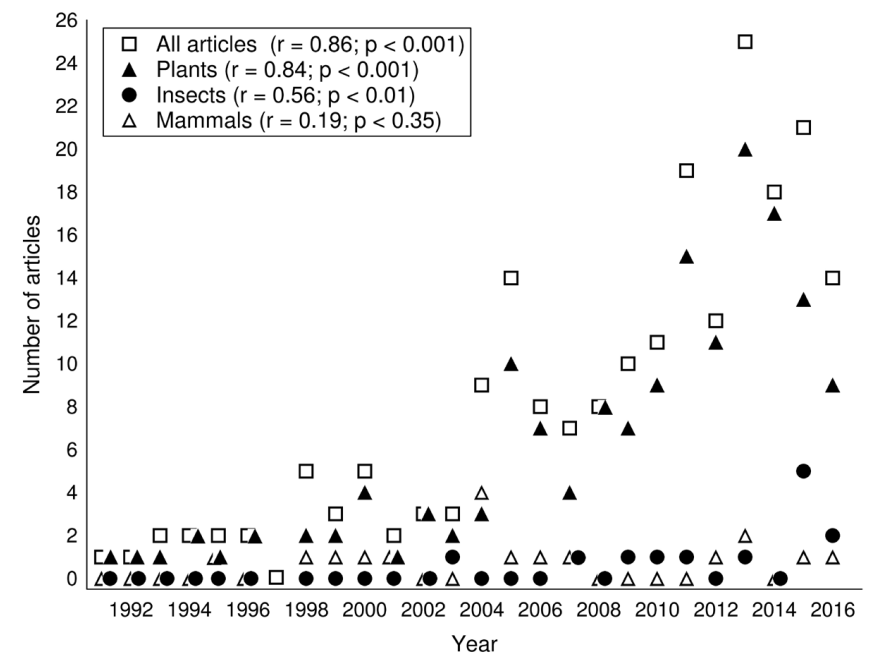

Figure 1. Temporal tendency of the total number of articles and number of articles involving insects, mammals and plants related to fire in the Cerrado from 1991 to 2016 
was the effect of fire on soil and nutrients. Only 12 articles (4\%) reported interactions (biotic interactions or interaction between organisms and the abiotic environment).

We identified the studied taxa in 207 articles and observed the predominance of studies involving plants, 155 publications (75\%), followed by mammals with 17 (8\%) and insects with $13(6 \%)$ publications (Figure 2). The remaining taxa comprise 22 publications $(11 \%)$ and each one has less than 10 publications (Figure 2). Among the taxa with the highest number of publications, plants $(r=0.84 ; p<0.001)$ and insects $(r=0.56 ; p<0.01)$ showed an increase in the number of articles across the years (Figure 1). We did not observe any temporal trend in the number of publications for mammals $(r=0.19, p=0.35)$ (Figure 1$)$. Due to the low number of studies, we did not perform inferential analyses to microorganisms, lichens, reptiles, humans, invertebrates (except insects), and birds.

We found 115 journals with articles addressing fire in the Cerrado. However, the number of articles published in these journals is asymmetric, since about $40 \%$ of them were published in only 13 journals. The journal
Acta Botanica Brasilica published the highest number of articles (20 articles) about this theme, representing $7 \%$ of the total (Figure 3).

We identified the state in 285 articles and $14 \%$ of these studies were performed in more than one state (39 studies). For studies restricted to just one Brazilian political unit, the major part of them ( 89 or $31 \%$ ) was done in the Federal District (Figure 4). The states of Minas Gerais and Goiás (35 studies or $12 \%$ each), Mato Grosso and São Paulo (28 or 10\% each) are where most of the research was conducted (Figure 4 ). About $11 \%$ of the publications were performed in the remaining states (Tocantins, Roraima, Pará, Mato Grosso do Sul, Bahia, Amapá, Maranhão, Piauí and Rondônia) and each State has less than 5\% of all publications (Figure 4).

The number of studies performed in each state was positively correlated with the number of first authors with an institutional address associated with that state $(r=0.80, p<0.001)$. The fire frequency in each state was not correlated with either the number of articles per state $(r=0.08, p=0.73)$ nor with the number of first authors affiliated to an institution located in the state $(r=-0.13, p=0.59)$. The spatial distribution of these three variables

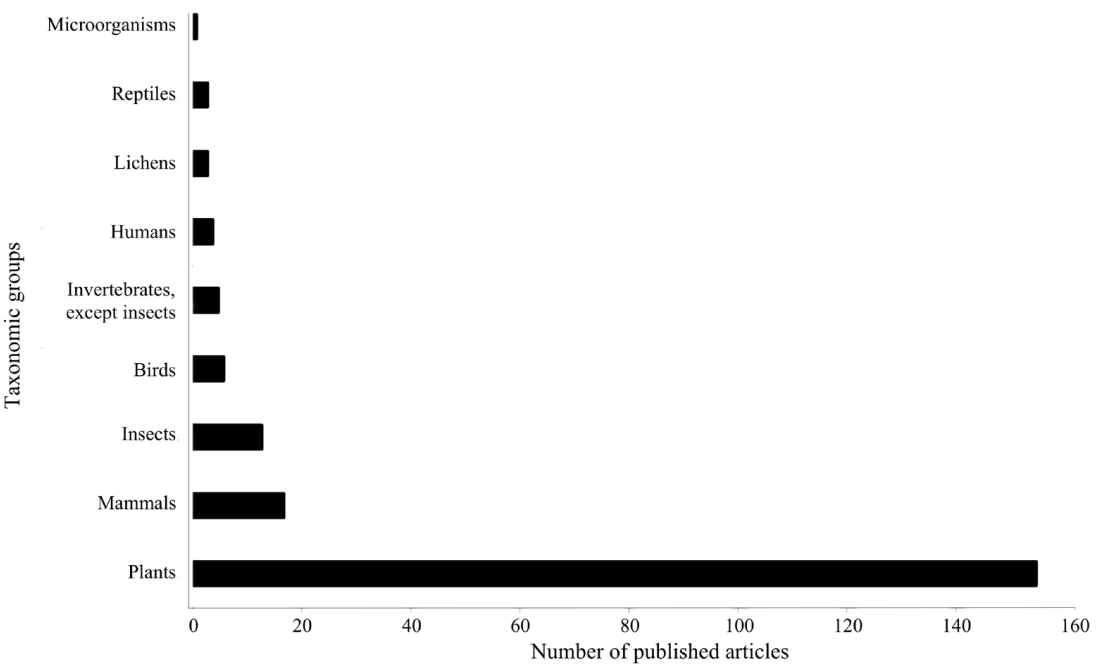

Figure 2. Taxonomic groups addressed in scientific articles about fire in the Cerrado from 1991 to 2016

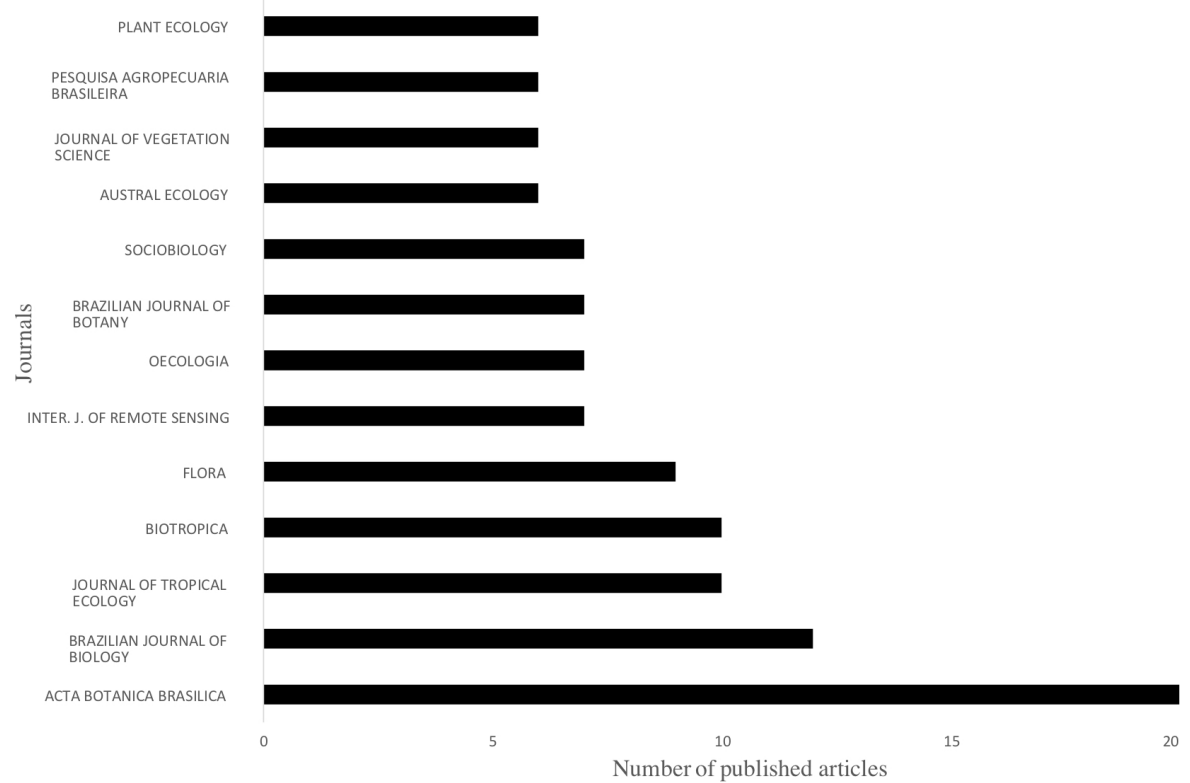

Figure 3. Journals with the highest number of articles about fire in the Cerrado from 1991 to 2016 
A
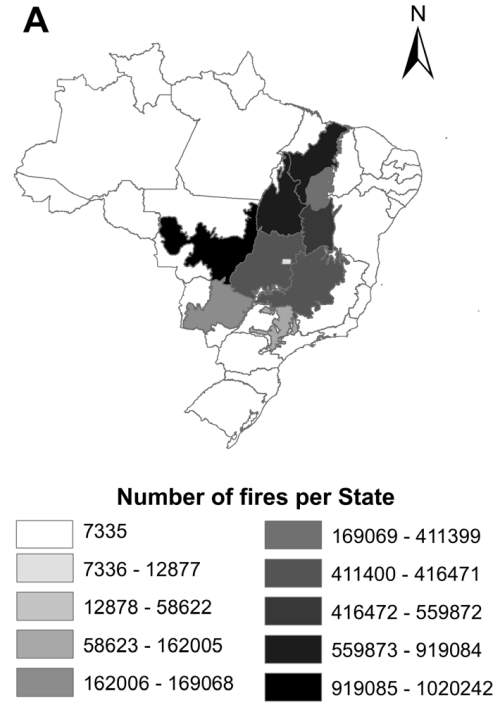

B

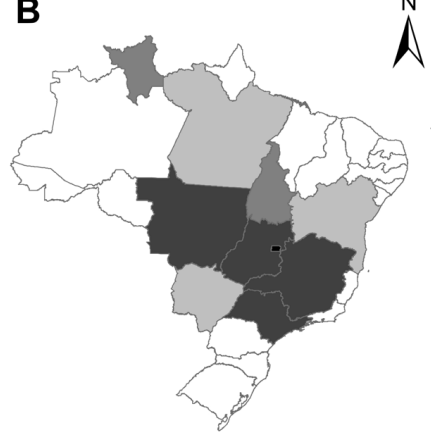

Number of articles per State

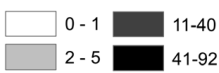

$-10$

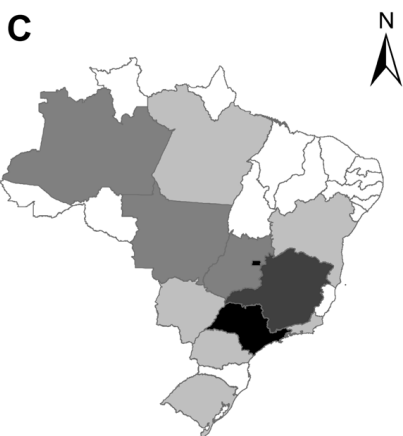

Number of first authors per State

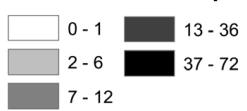

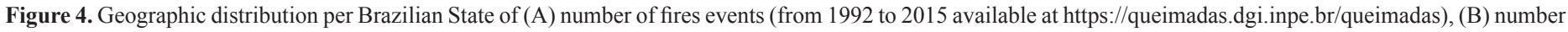
of articles and (C) number of first authors affiliated

demonstrates asymmetry in the distribution of fire occurrence, studies location and researchers' institutional affiliation (Figure 4). Fire occurrence is more frequent in the Cerrado areas bordering the Amazon rainforest (Figure 4), while location where research was conducted and affiliation of researchers are mainly in the southeast and central-west states of Brazil (Figure 4).

\section{Discussion}

We found that the number of publications about fire in the Cerrado has increased over the years and this trend was about the same for the literature involving the Cerrado $(\mathrm{r}=0.86$ in the present study $v s . \mathrm{r}=0.89$ in Borges et al. 2015). Thus, the interest about fire in the Cerrado reflects the interest in the biome by itself. Additionally, the growing interest in the effects of fire in the Cerrado may be due to the biome complexity: both high and low frequencies of fire can have negative effects on biodiversity (Anjos et al. 2016, Maravalhas \& Vasconcelos 2014, Abreu et al. 2016), and proper fire management programs based on scientific knowledge are still in development (Durigan \& Ratter 2016). Our results also indicate that most publications were about the effects of fire on plants, and were performed in states with fewer fire events. These asymmetries limit generalizations of the observed patterns that may not be applicable to the whole biome. In Brazil, there is a growing demand to create fire policies to conserve the Cerrado (Durigan \& Ratter 2016). Thus, an unbiased knowledge about the effects of fire on different taxa and regions of the biome is desirable to create clear guidelines for future fire management policies.

Even though fire has become an international issue due to its biodiversity and atmospheric consequences (Miranda et al. 2009, Bustamante et al. 2012), most studies were conducted by researchers from Brazilian institutions. These results demonstrate the importance of Brazilian universities and research institutions in this field. Thus, the recent cuts in Brazilian research investments (Fearnside 2016, Gibney 2015, Angelo 2017) may directly impact the generation of knowledge applied to Cerrado preservation, especially due to the lack of scientific background in fire management policies and consequences of both fire effects and fire suppression.

Although the number of journals publishing articles related to fire in the Cerrado biome is high, the distribution of the theme among them is clearly asymmetrical. A small number of journals is responsible for the great majority of publications. The Brazilian journals Acta Botanica Brasilica and Brazilian Journal of Biology stand out. Nevertheless, besides these two journals, international journals dominate the articles publication assessing fire in the Cerrado. This demonstrates the global interest in this subject, which is directly related to greenhouse gas emissions and climate change, which are currently two of the greatest issues facing humanity (Moraes et al. 2011). Moreover, similar to the Cerrado, there are other biomes where fire exerts a constant pressure. This demonstrates that the issue of fire is not only applicable to a regional context.

Among the different studied taxa, plants were the most frequent in articles about fire in Cerrado (Borges et al. 2015). Since the journal Acta Botanica Brasilica has a botanical perspective, this may be a possible reason for the higher number of publications about fire and vegetation in the Cerrado in this journal. Furthermore, the great vegetation diversity, the high endemism rates and the high risk of species extinctions (Myers et al. 2000) seem to explain the higher interest about the effects of fire in plants. Also, the plant's adaptations to fire are diverse and attract interest in this field (e.g. Eiten 1972, Ratter et al. 1997, Simon et al. 2009). Moreover, there are fewer studies performed on other taxa, which demonstrates the insufficient knowledge regarding the effects of fire on the general biodiversity. By reviewing the studies regarding the effect of fire on the Brazilian savanna fauna, Frizzo et al. (2011) found a great shortage of studies, which according to them, besides limiting knowledge, might induce generalizations that do not reflect the real effects of fire on animal communities. The fact that some animal taxa have a different number of specialists, demands more complex logistic and infrastructure to be studied, may have an influence on the low number of published articles about them (Agostinho et al. 2005, Borges et. al. 2015). Therefore, investment in research on other animal groups in the Cerrado is necessary for a better comprehension about the effects of fire on biodiversity.

We gathered evidence showing that the studies involving the effects of fire in the Cerrado are not evenly distributed. There is a tendency for studies to be regionally concentrated, with a particular concentration in the Federal District. A great part of this production occurred in the IBGE (Brazilian Institute of Geography and Statistics) Ecological Reserve - RECOR. Created 
in 1975, the RECOR has been established as an important research center of the Cerrado biome, mainly by the creation of a Long-Term Ecological Research - LTER (PELD in Portuguese) developed in collaboration between the IBGE and the University of Brasilia - UnB (http://recor.org. br). This concentration of studies brings some limitations to summarize what we currently know about the effects of fire on the Cerrado. Although a large number of species have broad distributions, the plant communities of the Cerrado sensu stricto harbor a high number of locally restricted species, as a consequence of climatic and geomorphological heterogeneity (Felfili \& Silva Júnior 2005, Françoso et al. 2016). In fact, different studies have confirmed high beta diversity among regions within the Cerrado (Lindoso \& Felfili 2007, Lopes et al. 2011). Furthermore, the Cerrado is surrounded by Pantanal, Amazon rainforest, Caatinga and Atlantic Forest biomes with distinct floristic composition in the transition areas (ecotones) (Maracahipes et al. 2011, Lima et al. 2015).

Fire can also affect the strata of the flora in different ways. Frequent burnings can damage the woody strata and make the areas more open, decreasing diversity over time (Libano \& Felfili 2006). Absence of fire in turn may reduce the diversity of herbaceous savanna specialists plants due to the low light availability promoted by forest canopy (Abreu et al. 2017). The fauna can also be affected in different ways, depending on the taxonomic group and the intensity of the fires. For instance, arthropod abundance can be lower in burned rupestrian fields over two years after a fire event (Anjos et al. 2016). On the other hand, Xenarthrans (e.g. armadillos and anteaters) probably use burned areas to obtain food resources such as termites and ants (Prada \& Marinho-Filho 2004). Ant diversity is reduced in a fire suppression scenario (Abreu et al. 2017) and lizard abundance responds negatively to both fire suppression and high intensity fires (Sousa et al., 2015). Considering the great heterogeneity within the Cerrado, caution is needed when generalizing conclusions about the effects of fire on the whole biome from studies carried out in restricted regions. This issue is particularly important once studies that evaluate the effect of fire on biotic and abiotic components can promote public policies of fire management within and nearby legally protected areas.

Lastly, the most studied locations are not those where higher fire frequency is observed. Most study sites are in the region of the study author's institution, usually far from the agricultural frontier (e.g., Deforestation Arch and region called MATOPIBA), where the major proportion of fires is observed. This geographic bias in research is concentrated in regions with higher Gross Domestic Product (GDP), such as São Paulo and Federal District, where universities are concentrated (Moerman \& Estabrook 2006, Pautasso \& McKinney 2007, Boakes et al. 2010, Nabout et al. 2012). Nevertheless, in states where fire events are more frequent (e.g. Tocantins e Maranhão) studies are scarce. Therefore, we assert the need for investment in research in areas with high fire frequency and the need for an increase in knowledge about these effects on the biota.

\section{Conclusion}

Despite the increase in the number of articles published about the effects of fire on the Cerrado over the years, the main focus of these studies is on the impacts of fire on vegetation, with an evident gap in knowledge related to animal groups. Most studies are concentrated in few states, particularly those with a lower fire incidence. This shows a clear imbalance in our knowledge about the effects of fire on the Cerrado. In addition, evidence from the literature has shown that the response of biodiversity to fire is context-dependent. In this scenario, the development of public policies for effective and specific fire management would depend on research efforts driven to overcome the spatial bias in knowledge about the effects of fire on the Cerrado.

\section{Acknowledgments}

FVA and DGS were supported by FAPEG and CAPES scholarships. FBT and HFC thanks to CNPq for productivity fellowships. University Research and Scientific Production Support Program (PROBIP/UEG) supported VHMP. FAPEMAT (process 329703/2012) supported TJI. The authors thank to Lucas Tomazett for the assistance with the maps.

\section{Author Contributions}

Filipe Viegas de Arruda and Diego Guimarães de Sousa participated in all stages of the research.

Fabrício Barreto Teresa, Vitor Hugo Mendonça do Prado, Hélida Ferreira da Cunha, and Thiago Junqueira Izzo participated in the analysis of data, writing and revisions of the article.

\section{Conflicts of interest}

The authors declare that they have no conflict of interest related to the publication of this manuscript.

\section{References}

ABREU, R.C.R., HOFFMANN, W.A., VASCONCELOS, H.L., PILON, N.A, DAVI R. ROSSATTO D.R. \& DURIGAN, G. 2017. The biodiversity cost of carbon sequestration in tropical savanna. Sci. Adv. 3(8): e1701284

AGOSTINHO, A.A., THOMAZ, S.M. \& GOMES, L.C. 2005. Conservation of the biodiversity of Brazil's inland waters. Conserv Biol. 19(3): 646-652.

ANGELO, C. 2017. Brazilian scientists reeling as federal funds slashed by nearly half. Nature. 533: 301.

ANJOS, D., ALVES-SILVA, E. \& RIBEIRO, S.P. 2016. Do fire and seasonality affect the establishment and colonisation of litter arthropods? J Insect Conserv. 20: 653-661.

BOAKES, E.H., MCGOWAN, P.J.K., FULLER, R.A., CHANG-QING, D., CLARK, N.E., O'CONNOR, K. \& MACE, G.M. 2010. Distorted Views of Biodiversity: Spatial and Temporal Bias in Species Occurrence Data. Plos Biol. 8(6): 1-11.

BORGES, P.P., OLIVEIRA, K.A.F.A., MACHADO, K.B., VAZ, U.L., CUNHA, H.F. \& NABOUT JC. 2015. Tendências e lacunas da literatura científica sobre o bioma Cerrado: uma análise cienciométrica. Neotrop. Biol. Conserv. 10: 2-8.

BOWMAN, D.M.J.S., BALCH, J., ARTAXO, P., BOND, W.J., COCHRANE, M.A., D’ANTONIO, CM., DEFRIES, R., JOHNSTON, F.H., KEELEY, J.E., KRAWCHUK, M.A., KULL, C.A., MACK, M., MORITZ, M.A., PYNE, S., ROOS, C.I., SCOTT, A.C., SODHI, N.S.\& SWETNAM, T.W. 2011. The human dimension of fire regimes on Earth. J Biogeogr. 38: 2223-2236.

BUSTAMANTE, M.M.C., NOBRE, C.A., SMERALDI, R., AGUIAR, A.P.D., BARIONI, L.G., FERREIRA, L.G., LONGO, K., MAY, P., PINTO, A.S. \& OMETTO, J.P.H.B. 2012. Estimating greenhouse gas emissions from cattle raising in Brazil. Climatic Change. 115: 559 - 577.

CARDOSO, E., MORENO, M.I.C., BRUNA, E.M. \& VASCONCELOS, H.L. 2009. Mudanças fitofisionômicas no Cerrado: 18 anos de sucessão ecológica na Estação Ecológica do Panga, Uberlândia - MG. Caminhos de Geografia. 10: 254-268.

COUTINHO, L.M. 1990. Fire in the Ecology of Brazilian Cerrado. In 'Fire in the tropical biota: Ecological processes and global challenges'.(J.G, Goldammer, ed.) p. 82-105. (Springer-Verlag: Berlin)

DURIGAN, G. \& RATTER, J.A. 2016. The need for a consistent fire policy for Cerrado conservation. J Appl Ecol. 53: 11-15.

EITEN, G. 1972. The cerrado vegetation of Brazil. Bot Rev. 38: 201-341.

FAGUNDES, R., ANJOS, D.V., CARVALHO, R. \& DEL-CLARO, K. 2015. Availability of Food and Nesting-sites as Regulatory Mechanisms for the Recovery of Ant Diversity After Fire Disturbance. Sociobiology. 62(1): 1-9.

FELFILI, J.M. \& SILVA-JÚNIOR, M.C. 2005. Diversidade alfa e beta no Cerrado sensu strictu, Distrito Federal, Goiás, Minas Gerais e Bahia. In 'Cerrado: Ecologia, Biodiversidade e Conservação'. (Scariot, A., Sousa-Silva,J.C. \& Felfili, J.M. eds) pp.143-154. (Ministério do Meio Ambiente: Brasília). 
FEARNSIDE, P.M. 2016. Brazilian politics threaten environmental policies. Science. 353(6301):746-748.

FRANÇOSO, R.D., HAIDAR, R.F. \& MACHADO, R.B. 2016 Tree species of South America central savanna: endemism, marginal areas and the relationship with other biomes. Acta Bot. Bras. 30(1): 78-86.

FRIZZO, T.L.M., BONIZÁRIO, C., BORGES, M. P. \& VASCONCELOS, H.L. 2011. Revisão dos Efeitos do Fogo Sobre a Fauna de Formações Savânicas do Brasil. Oecologia Australis. 15: 365- 379.

FURLEY, P.A. 1999. The nature and diversity of neotropical savanna vegetation with particular reference to the Brazilian cerrados. Glob. Ecol. Biogeogr. 8: 223-241.

GIBNEY, E. 2015. Brazilian science paralysed by economic slump. Nature. 526: 16-17.

LENTHALL, J., BRIDGEWATER, S. \& FURLEY, P.A. 1999. A phytogeographic analysis of the woody elements of New World savannas. Edinb. J. Bot. 56 293-305.

LIBANO, A.M. \& FELFILI, J.M. 2006. Mudanças temporais na composição florística e na diversidade de um cerrado sensu stricto do Brasil Central em um período de 18 anos (1985-2003). Acta Bot. Bras. 20: 927-936.

LIMA, R.A.F. RANDO, J.G. \& BARRETO, K.D. 2015. Composição e diversidade no cerrado do leste de Mato Grosso do Sul, Brasil. Rev. Árvore. 39 (1): 9-24.

LINDOSO, G.S. \& FELFILI, J.M. 2007. Características florísticas e estruturais de Cerrado sensu stricto em Neossolo Quartzarênico. Rev. Bras. Biociênc. 5(2): 102-104

LOPES, S.F., VALE, V.S., OLIVEIRA, A.P. \& SCHIAVINI, I. 2011. Análise comparativa da estrutura e composição florística de Cerrado no Brasil Central. Interciencia. 36(1): 8-15.

MARACAHIPES, L., LENZA, E., MARIMON, B.S., OLIVEIRA, E.A., PINTO, J.R.R. \& MARIMON JUNIOR, B.H. 2011. Structure and floristic composition of woody vegetation in cerrado rupestre in the Cerrado-Amazonian Forest transition zone, Mato Grosso, Brazil. Biota Neotrop. 11(1): 133-141.

MARAVALHAS, J. \& VASCONCELOS, H.L. 2014 Revisiting the pyrodiversitybiodiversity hypothesis: long-term fire regimes and the structure of ant communities in a Neotropical savanna hotspot. J Appl Ecol. 51, 1661-1668.

MENDONÇA, R.C., FELFILI, J.M., WALTER, B.M.T., SILVA JÚNIOR, M.C., REZENDE, A.V., FILGUEIRAS.T.S., NOGUEIRA, P.E. \& FAGG, C.W. 2008 Flora vascular do bioma cerrado: checklist com 12356 espécies. In Cerrado: ecologia e flora (Sano, S.M. \& Almeida, S.P. \& Ribeiro, J.F. eds). (Embrapa Cerrados. Vol. 2).

MIRANDA, H.S., SATO, M.N., NASCIMENTO-NETO, R. \& AIRES, F.S. 2009. Fires in the cerrado, the Brazilian savanna. (M.A. Cochrane ed.). Tropical fire ecology: climate change, land use, and ecosystem dynamics, p. 427-450. Chichester, Springer-Praxis.

MYERS. N., MITTERMEIER, R.A., MITTERMEIER, C.G., FONSECA, G.A.B. \& KENT, J. 2000. Biodiversity hotspots for conservation priorities. Nature. 403: $853-858$

MOERMAN, D.E. \& ESTABROOK, G.F. 2006. The botanist effect: counties with maximal species richness tend to be home to universities and botanists. J Biogeogr. 33: 1969-1974.

MORAES, W.B., JESUS JUNIOR, W.C., MORAES, W.B. \& CECÍLIO, R.A. 2011 Potenciais impactos das mudanças climáticas globais sobre a agricultura. Rev. Trópica - Ciências Agrárias e Biológicas. 5: 3-14.

MOREIRA, A.G. 2000. Effects of fire protection on savanna structure in Central Brazil. J Biogeogr. 27: 1021-1029.

NABOUT, J.C., CARNEIRO, F.M., BORGES, P.P., MACHADO, K.B. \& HUSZAR, V.L.M. 2015. Brazilian scientific production on phytoplankton studies: national determinants and international comparisons. Braz J Biol. 75(1): 216-223.

NABOUT, J.C., CARVALHO, P., PRADO, U.M., BORGES, P.P., MACHADO, K.B., HADDAD, K.B., MICHELAN, T.S., CUNHA, H.F. \& SOARES, T.N 2012. Trends and Biases in Global Climate Change Literature. Nat Conservacao. 10(1): 45-51

OLIVEIRA-FILHO, A.T. \& RATTER JA. 2002. Vegetation Physiognomies and Woody Flora of the Cerrado Biome. In 'The Cerrados of Brazil Ecology and Natural History of a Neotropical Savanna.'(Oliveira P.S, \& Marquis, R.J. eds) p. 91-120. (Columbia University Press: New York).
OLIVERAS, I., MEIRELLES, S.T., HIRAKURI, V.L., FREITAS, C.R., MIRANDA, H.S. \& PIVELLO, V.R. 2012. Effects of fire regimes on herbaceous biomass and nutrient dynamics in the Brazilian savanna. Int J Wildland Fire. 22: 368-380

PAUTASSO, M. \& MCKINNEY, M.L. 2007. The botanist effect revisited: Plant species richness, county area and human population size in the United States. Conserv Biol. 21: 1333-1340.

PEREIRA JÚNIOR, A.C., OLIVEIRA, S.L.J., PEREIRA, J.M.C. \& TURKMA, M.A.A. 2014. Modelling Fire Frequency in a Cerrado Savanna Protected Area. Plos ONE. 9: 1-11.

PINHEIRO, E.S. \& DURIGAN, G. 2009. Dinâmica espaço-temporal (1962-2006) das fitofisionomias em unidade de conservação do Cerrado no sudeste do Brasil. Rev. Bras. Bot. 32: 441-454

PINHEIRO, M.H.O., AZEVEDO, T.S., MONTEIRO, R. 2010. Spatial-temporal distribution of fire-protected savanna physiognomies in Southeastern Brazil Na. Acad. Bras. Ciênc. 82: 379-395.

PIVELLO, V.R. 2011. The use of fire in the cerrado and Amazonina rainforest of Brazil: past and present. Fire Ecol. 7: 24-39.

PRADA, M. \& MARINHO-FILHO, J. 2004. Effects of fire on the abundance of Xenarthrans in Mato Grosso, Brazil. Austral Ecol. 29: 568-573.

QUEIROZ-NETO, J.P.DE 1982. Solos da região dos cerrados e suas in terpretacões (revisão de literatura). Rev. Bras. Ciên. Solo. 6: 1-12.

RATTER, J.A., RIBEIRO, J.F. \& BRIDGEWATER, S. 1997. The Brazilian Cerrado vegetation and threats to its biodiversity. Ann Bot-London. 80:223-230.

REATTO, A., CORREIA, J.R. \& SPERA, S.T. 1998. Solos do bioma Cerrado: aspectos pedológicos. In: SANO S.M. AND ALMEIDA S.P. (eds), Cerrado: Ambiente e Flora. Embrapa, Planaltina, p. 4786.

RIBEIRO, J.F. \& WALTER, B.M.T. 2008. As principais fitofissionomias do bioma Cerrado. In 'Cerrado ecologia e flora' (Eds SANO SM, ALMEIDA SP, RIBEIRO JP) p. 153-212. (Embrapa: Brasília).

ROITMAN, I., FELFILI, J.M. \& REZENDE, A.V. 2008. Tree dynamics of a fi reprotected cerrado sensu stricto surrounded by forest plantations over a 13-year period (1991-2004) in Bahia, Brazil. Plant Ecol. 197: 255-267

SILVA, J.M.C. \& BATES, J.M. 2002. Biogeographic patterns and conservation in the South American Cerrado: a tropical savanna hotspot. BioScience. 52: 225-233.

SILVA, J.F., FARIÑAS, M.R., FELFILI, J.M. \& KLINK, C.A. 2006. Spatial heterogeneity, land use and conservation in the cerrado region of Brazil. J. Biogeogr. 33(3): 536-548

SILVÉRIO, D.V., PEREIRA, O.R., MEWS, H.Á., MARACAHIPES-SANTOS, L., SANTO,S J.O. \& LENZA E. 2015. Surface fire drives short-term changes in the vegetative phenology of woody species in a Brazilian savanna. Biota Neotrop. 15(3): 1-9

SIMON, M.F., GRETHER, R., QUEIROZ, L.P., SKEMA, C., PENNINGTON, R.T. \& HUGHES, C.E. 2009. Recent assembly of the Cerrado, a neotropical plant diversity hotspot, by in situ evolution of adaptations to fire. P Natl Acad Sci-Biol. 106: 20359-20364.

SOUSA, H.C., SOARES, A.H.B., COSTA, B.M., PANTOJA, D.L., CAETANO, G.H., QUEIROZ, T.A. \& COLLI, G.R. 2015. Fire regimes and the demography of the lizard Micrablepharus atticolus (Squamata, Gymnophthalmidae) in a biodiversity hotspot. S. Am. J. Herpetol. 10, 143-156.

TUBELIS, D.P. 2009. Bird foraging in Anacardium patches in central brazilian fire breaks: relationship between flock size and patch size. Ornitol. Neotrop. 3: 421-230.

VIEIRA, E.M. \& BRIANI, D.C. 2013. Short-term effects of fire on small rodents in the Brazilian Cerrado and their relation with feeding habits Int J Wildland Fire. 22: 1063-1071.

WENDLING B., JUCKSCH, I., MENDONÇA, E.S., ALMEIDA, R.F. \& ALVARENGA, R.C. 2014. Simulation using the Century Model of the Carbon and Nitrogen Stocks in Latosols of the Brazilian Cerrado. Rev. Ciênc. Agron. 45(2): 238-248.

Received: $16 / 08 / 2017$

Revised: 05/01/2018

Accepted: 16/01/2018

Published online: 05/03/2018 